\title{
Revamped Delbrück centre enters new era
}

Heidelberg. Bringing East Berlin's Max Delbrück Centre for Molecular Medicine up to western standards has been a hard and painful process. But Detlev Ganten, its director, believes that the worst is over

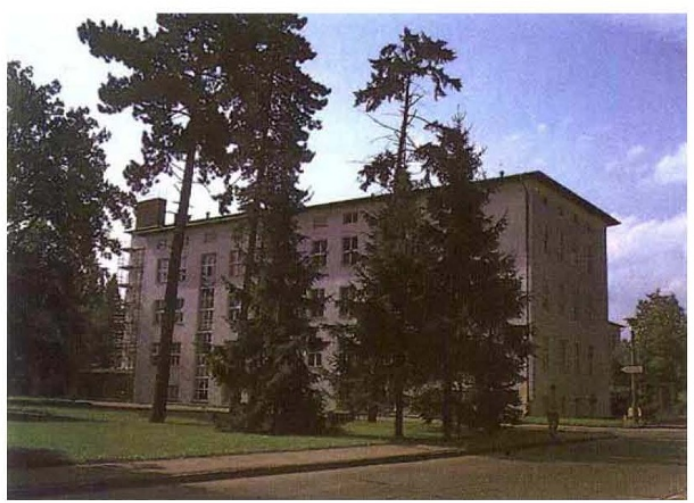

The reopened Delbrück centre

and that the revamped centre, which reopened earlier this month, stands a good chance of living up to its illustrious past.

A biological institute on the Max Delbrück site was founded in the 1930s by the Kaiser Wilhelm Society, the forerunner of the Max Planck Society. The institute, which specialized in brain research, attracted the best of German scientists as well as occasional notoriety, as when neurologist Oskar Vogt was summoned to Moscow by Joseph Stalin to dissect Lenin's brain as a way of unravelling the 'anatomy of genius'. (Although Vogt found nothing more unusual than a few enlarged cells in the hippocampus, Stalin heralded the observation as the source of all genius.)

The institute survived the war and was retained as a research centre - expanding into three institutes - by the East German National Academy of Science. In 1989 , after reunification, the research centre once again demonstrated its power of survival by passing muster with the Bonnbased AGF, which funds and administers national research centres. Only one of its three institutes, the Max Stelbourg, has been redeveloped, along with cardiovascular and cancer clinics that together have 300 beds.

As with all East German institutes, however, the Max Stelbourg was heavily overstaffed. And Ganten, who became director in September 1991, has had the unhappy task of shedding more than half of the 1,600 employees. Recognizing the need to staunch the outflow of talent, Ganten retained as many researchers as possible on short-term contracts and arranged for 250 others to receive special government 'rescue' grants that allowed them to continue working without actually being employed. He also encouraged the formation of individual pharmaceutical companies ( 25 now exist) by staff from the applied pharmaceutics department in the old research centre.

The streamlined Max Delbrück centre now plans to support 20 permanent professorships or group leaders, as well as 350 employees in experimental research, 112 of whom are research scientists, and 400 people in the two clinics. Ganten's goal is to give permanent positions to $20-30$ per cent of the staff, a level appropriate to the competitive field of molecular medicine. Equally important to Ganten is restoring the centre's links to the universities. Both clinics are incorporated into the Free University of Berlin, and professors of experimental medicine will be affiliated with either the Humboldt or the Free universities.

Despite the project's success in western terms, Ganten remains sensitive to the depression that pervades eastern Germany. He says that his western compatriots are still seen as "brutal in their efficiency, colonizing their country and forcing a system on them that has caused hardship for so many".

Nonetheless, Ganten is proud of what he has done. He abandoned a comfortable life at the University of Heidelberg for a gamble that, so far, appears to be paying off.

Alison Abbott

\section{\$100 million pledged to support ex-Soviet science}

Washington. Plans by a US philanthropist to spend $\$ 100$ million on science in the former Soviet Union during the next several years must somehow find a way to overcome the logistical nightmare of finding and funding the right scientists.

George Soros, a financier who made a billion dollars earlier this year by betting on the devaluation of the British pound, announced last week that his new International Science Foundation for the Former Soviet Union will dispense its first grants early next year. But foundation officials admit that the target countries are just starting to create a system to handle such largesse.

The gift dwarfs existing efforts to help ex-Soviet scientists. The United States, European Communities, Canada and Japan have pledged $\$ 70$ million to help former weapons scientists in Russia and another $\$ 12$ million for those in Ukraine, but after nearly a year the first grants have yet to be awarded. The American Physical Society, with help from Soros, the Sloan Foundation and the National Science Foundation, has amassed $\$ 700,000$ to distribute directly to needy scientists, avoiding government bureaucracy. And the Howard Hughes Medical Institute has just announced a five-year programme to spend $\$ 14$ million to bolster research in the former Soviet Union.

According to preliminary plans, the foundation will first devise a system for distributing the bulk of the money. About $\$ 6$ million will be spent on 'emergency projects', with half allocated to salaries and the rest to libraries and a telecommunications system. Scientists from every former Soviet republic can qualify by filling out a brief, simplified grant application or by having already undergone peer review in the West.

In the second phase of the project, the foundation plans to solicit Western-style applications and have them reviewed by committees of scientists from around the world. In mid-year, the foundation hopes to begin awarding 300-500 grants, averaging $\$ 100,000$, for salaries, supplies and equipment. The rest of the money will be spent on infrastructure. Soros plans to commit if not spend - all the money by the end of 1994.

But the foundation faces obstacles that have dissuaded other charitable groups. Because the republics lack a reliable banking system, foundation officials have proposed an electronic network for wiring money directly to researchers. But US regulations and high costs may make this plan unworkable. Nor will it be easy to ensure that the researchers who get funded are the most deserving. Many scientists who have never written a grant application will have only until mid-1993 to prepare one. "Those people who are quickest to learn how to write a proposal are not always the best", says Edward Shuryak, a physicist at the State University of New York, Stony Brook, who left the Soviet Union in 1989.

Other Soviet émigrés worry that the money will not be enough to make a permanent difference in an otherwise desperate economic situation. Even Alexander Goldfarb, the foundation's temporary director, has taken a wait-and-see attitude. "It's a huge experiment", Goldfarb says. "We'll see in six months whether it works or whether it just made a huge splash".

Traci Watson 